\title{
Influence of the Kaolinite Calcination Conditions on the Compressive Strength of Geopolymer
}

\section{Carolina Braccini Freire, Bruno Lourencio Dias dos Santos, Isabella Lobo Filgueiras de Miranda, Moacyr Avellar Rodrigues, and Fernando Soares Lameiras}

Centro de Desenvolvimento da Tecnologia Nuclear - CDTN - Belo Horizonte/MG, Brasil Comissão Nacional de Energia Nuclear - CNEN

\section{Abstract}

Among the cementitious materials, geopolymers not only attract interest due to the low emission of $\mathrm{CO}_{2}$ in their manufacturing process, but also because of their good mechanical and chemical properties, together with their resistance to fire. They can be made from different raw materials including various wastes from industrial activities and mineral extraction. In this study, metakaolin was obtained from kaolinite calcined under different conditions. In this case kaolinite is a by-product of sand extraction. It was observed that the calcination conditions (kiln heating rate, calcination time and temperature) had a strong influence on the compressive strength of geopolymer after 28 days of cure. They also affected the composition of the geopolymer, which was prepared by mixing metakaolin, alkaline sodium silicate and sodium hydroxide solution. Compressive strengths in the range from $10 \mathrm{MPa}$ to $50 \mathrm{MPa}$ may be observed, depending on the combination of these factors. A factorial design of experiments allowed the isolation of the effect of each factor and its interactions, offering new insights into the complexity of the geopolymeric reactions and highlighting the need for a rigid control of the calcination conditions of kaolinite and the composition of the geopolymer samples to obtain the desired compressive strength.

et al. This article is distributed under the terms of the Creative Commons Attribution License, which permits unrestricted use and redistribution provided that the original author and source are credited.

Selection and Peer-review under the responsibility of the RICON19 - REMINE International Conference Conference Committee.

\section{G OPEN ACCESS}

\section{Introduction}

The manufacturing of Portland cement requires high energy consumption and generates emission of large amounts of $\mathrm{CO}_{2}$. About $5 \%$ of all $\mathrm{CO}_{2}$ emissions from human activity are originated from the production of Portland cement [1]. A significant growth of the cement industry is expected in the coming decades, especially in the developing countries [2]. Interest in geopolymers, whose production emits less $\mathrm{CO}_{2}$, is growing due to the possibility of reducing greenhouse gas emissions from Portland cement. 
Geopolymers, so named by Joseph Davidovits [3], are cementitious binders formed by alkali activated aluminosilicates. They have high mechanical strength, stability at high temperatures and in alkaline or acidic media. Synthesis occurs by means of polymerization or polycondensation reactions from the dissolution of $\mathrm{SiO}_{4}{ }^{4-}$ and $\mathrm{AlO}_{4}{ }^{5-}$ ions of the aluminosilicates in a highly alkaline solution. After dissolution, these ions are transported in the solution and rearranged in structures of polysialates, poly(siloxosialato) or poly(disiloxo-sialato) forming a three-dimensional network predominantly amorphous, composed of $\mathrm{SiO}_{4}$ and $\mathrm{AlO}_{4}$ tetrahedra [4]. The sources of aluminosilicates can be calcined clays, fly ash and some industrial residues, which makes geopolymers a sustainable product with interesting market potential [5].

In this study, samples of kaolinite from the company GH Areias were used (located in Inhaúma, Minas Gerais, Brazil). The samples had different greyish colors according to the depth at which they were collected. The gray coloration becomes darker at greater depths. In this company the kaolinite is a by-product of sand extraction for civil construction. Due to the difficulty of commercialization, the kaolinite is considered a residue, being stored in piles. The objective is to develop geopolymers from this kaolinite in order to obtain products with higher added value.

\section{Materials and Methods}

The kaolinite samples were characterized by X-ray diffraction, X-ray fluorescence, particle size distribution, specific surface area, density, infrared spectroscopy, and thermal analysis. They were dried at $120^{\circ} \mathrm{C}$ for 24 hours before comminution performed in jaw and planetary mills to reduce the particle size as much as possible. After sieving in 16 \# sieves, the retained portion was disaggregated with the use of rollers. The metakaolin was obtained by calcination of the kaolinite in trays in a muffle kiln under the conditions shown in Table 1. The calcining temperatures were chosen based on the results of thermal analysis.

The geopolymer samples were synthesized by mixing metakaolin with alkaline sodium silicate $\left(\mathrm{SiO}_{2} / \mathrm{Na}_{2} \mathrm{O}\right.$ molar ratio $\left.=2.22\right)$ and $10 \mathrm{M}$ sodium hydroxide solution. $\mathrm{A}$ paste was obtained which was placed in polyethylene cylindrical molds $(5 \mathrm{~cm}$ diameter and $5 \mathrm{~cm}$ height) and subjected to stirring on an orbital shaker at $350 \mathrm{rpm}$ for 10 minutes to remove air bubbles. After 24 hours at room temperature the hardened samples were desmolded. Based on the stoichiometric composition of $45 \mathrm{wt} \%$ of metakaolin (MK), 33 wt\% of sodium silicate (SS) and 22 wt\% of $\mathrm{NaOH}$ solution, seven compositions were made according to a simplex design done with Minitab (Figure 2). The two compositions 
TABLE 1: Calcination conditions of the kaolinite to obtain metakaolin

\begin{tabular}{|c|c|c|c|c|}
\hline \multicolumn{5}{|l|}{ First design } \\
\hline Temperature $\left({ }^{\circ} \mathrm{C}\right)$ & \multicolumn{4}{|l|}{800} \\
\hline Heating rate $\left({ }^{\circ} \mathrm{C} / \mathrm{min}\right)$ & \multicolumn{2}{|l|}{1} & \multicolumn{2}{|l|}{10} \\
\hline Calcination time (hour) & 1 & 2.8 & 4 & 8 \\
\hline \multicolumn{5}{|l|}{ Second design } \\
\hline Temperature $\left({ }^{\circ} \mathrm{C}\right)$ & 700 & & 800 & \\
\hline Heating rate $\left({ }^{\circ} \mathrm{C} / \mathrm{min}\right)$ & 1 & Code: -1 & 10 & Code: +1 \\
\hline Calcination time (hour) & 4 & & 8 & \\
\hline
\end{tabular}

that presented the best workability, best solidified product with lower porosity and no efflorescence were chosen. These compositions were referred to as A (55 wt\% MK, 25 wt\% SS and $20 \mathrm{wt} \% \mathrm{NaOH}$ ) and B (50 wt\% MK, $35 \mathrm{wt} \% \mathrm{SS}$ and $15 \mathrm{wt} \% \mathrm{NaOH}$ ). The geopolymer samples of compositions $A$ (code: -1 ) and $B($ code: +1 ) were characterized for compressive strength based on the Brazilian Standard NBR 5739: 2007 [6], after 28 days of curing at room temperature, in a $273 \mathrm{kN}$ press at a loading rate of $30 \mathrm{MPa} / \mathrm{min}$.

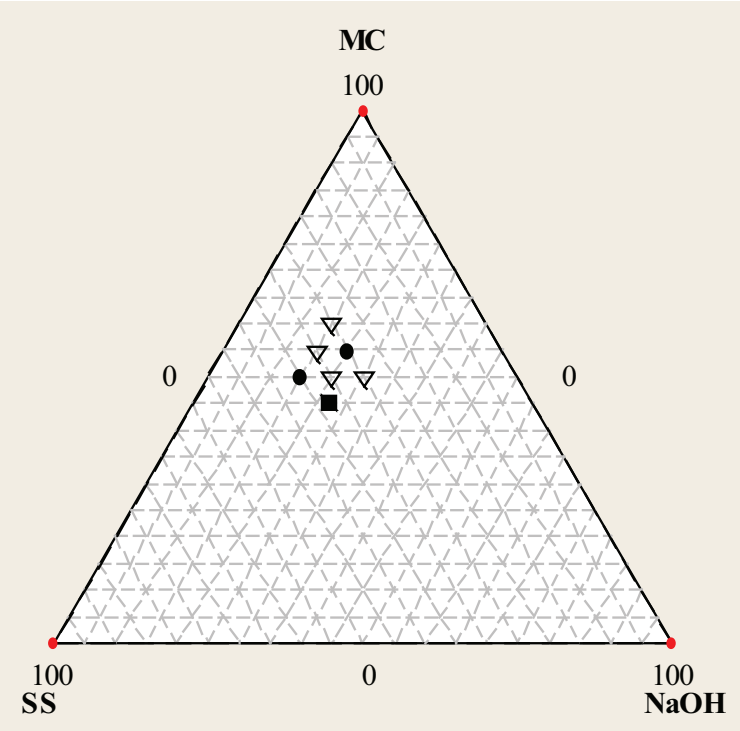

Figure 1: Simplex design where the square is the stoichiometric composition and the circles is the compositions A and B choice.

The first design of Table 1 comprised 16 runs ( 8 runs for each composition, A and $B$, respectively). The second design was a $2^{4}$ factorial design where the factors were calcination temperature $(T)$, calcination time $(C T)$, heating rate $(H R)$, and composition $(C)$ with 16 runs. The response was the compressive strength (CS) of the samples. Five or four specimens were measured for each run. 


\section{Results and Discussion}

Despite the difference in coloration, the kaolinite samples showed very similar X-ray diffractograms, with kaolinite as the major phase and quartz as a minority phase. $\mathbf{X}$-ray fluorescence also revealed similarity between the samples, except for the $\mathrm{Mn}$ and $\mathrm{Cr}$ contents, as well as the loss of mass on calcination, as shown in Table 2. Only the loss of mass on calcination correlates to the color tone, suggesting that the color is related to the presence of organic matter, since the calcined materials had slight to no color differences. The density of the samples varied between $2.54 \mathrm{~g} / \mathrm{cm}^{3}$ and $2.62 \mathrm{~g} / \mathrm{cm}^{3}$, probably due to quartz and organic matter contents. The mean particle size varied between $7.75 \mu \mathrm{m}$ and $11.05 \mu \mathrm{m}$.

TABLE 2: Composition of the kaolinite samples (X-rays fluorescence)

Composition
$\mathrm{MgO}$ (wt\%)
$\mathrm{Al}_{2} \mathrm{O}_{3}$ (wt\%)
$\mathrm{SiO}_{2}$ (wt\%)
$\mathrm{P}$ (ppm)
$\mathrm{S}$ (ppm)
$\mathrm{K}_{2} \mathrm{O}$ (wt\%)
$\mathrm{CaO}(w t \%)$
$\mathrm{Ti}(p p m)$
$\mathrm{V}(\mathrm{ppm})$
$\mathrm{Cr}(\mathrm{ppm})$
$\mathrm{Mn}(\mathrm{ppm})$
$\mathrm{Fe}{ }_{2} \mathrm{O}_{3}(w t \%)$
$\mathrm{Ni}(\mathrm{ppm})$
$\mathrm{Cu}(\mathrm{ppm})$
$\mathrm{Zn}(\mathrm{ppm})$
$\mathrm{Zr}(\mathrm{ppm})$
$\mathrm{Ba}(\mathrm{ppm})$
$\mathrm{Loss}$ of mass on calcination(\%)

\begin{tabular}{|c|c|}
\hline & Sample \\
\hline Light gray & Gray \\
\hline 0.16 & $<0.10$ \\
\hline 29.23 & 28.32 \\
\hline 51.02 & 48.92 \\
\hline 3421 & 3385 \\
\hline 111 & 110 \\
\hline 2.14 & 2.34 \\
\hline 0.38 & 0.39 \\
\hline 4660 & 4551 \\
\hline 112 & 110 \\
\hline 69 & 96 \\
\hline 93 & 230 \\
\hline 3.38 & 3.67 \\
\hline 19 & 11 \\
\hline 26 & 25 \\
\hline 85 & 126 \\
\hline 173 & 140 \\
\hline 592 & 580 \\
\hline 12.73 & 15.37 \\
\hline
\end{tabular}

\begin{tabular}{|c|}
\hline Dark grey \\
\hline 0.20 \\
\hline 25.60 \\
\hline 48.68 \\
\hline 3593 \\
\hline 121 \\
\hline 2.32 \\
\hline 0.31 \\
\hline 4662 \\
\hline 113 \\
\hline 42 \\
\hline 150 \\
\hline 5.10 \\
\hline 16 \\
\hline 26 \\
\hline 80 \\
\hline 180 \\
\hline 591 \\
\hline 16.40 \\
\hline
\end{tabular}

Thermal analysis of the samples reveals an endothermic peak around $500{ }^{\circ} \mathrm{C}$ (differential scanning calorimetry, DSC), which is related to the dehydroxylation of kaolinite (Figure 2). Around $250{ }^{\circ} \mathrm{C}$ there is a small peak that is probably related to the burning 
of organic matter. There is another small peak around $580^{\circ} \mathrm{C}$, which may be related to the transition from alpha-quartz to beta-quartz. At $980{ }^{\circ} \mathrm{C}$ there is an exothermic peak, related to mullite formation.

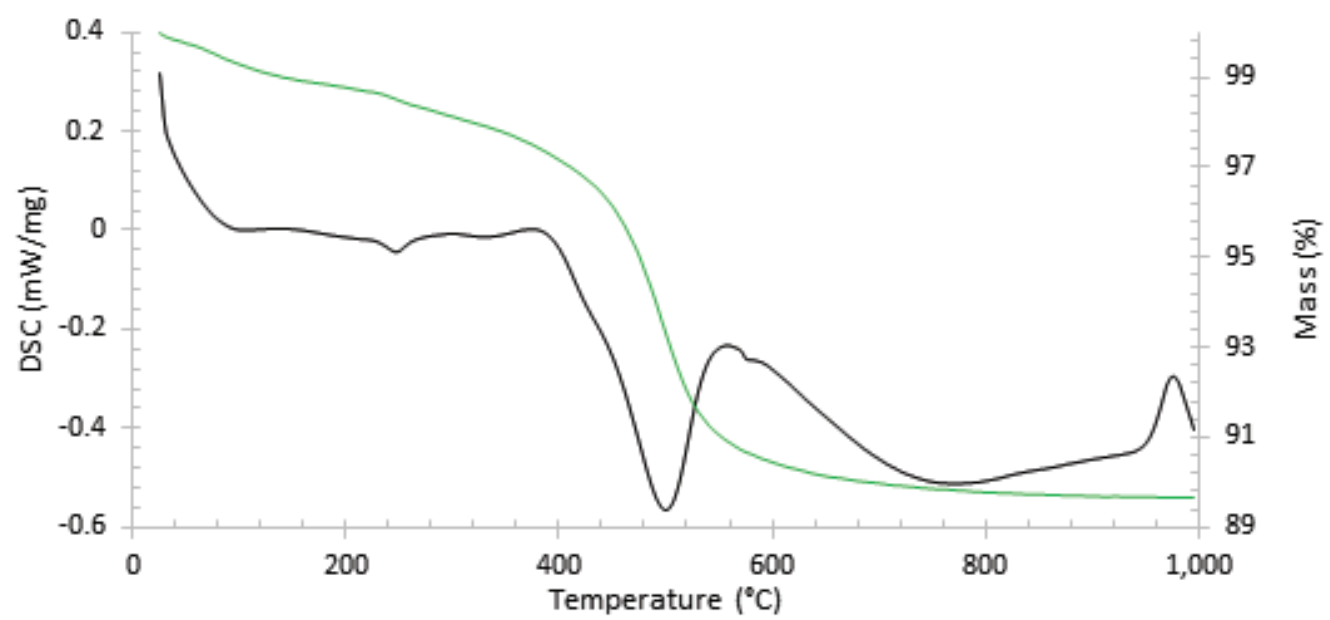

Figure 2: Typical result of thermal analysis of kaolinite samples after drying at $120{ }^{\circ} \mathrm{C}$ for 24 hours in air. Heating rate: $10^{\circ} \mathrm{C} / \mathrm{min}$, atmosphere: $\mathrm{N}_{2}$.

Figure 3 shows an example of infrared spectra of kaolinite samples before and after the calcination at $800{ }^{\circ} \mathrm{C}$ (formation of metakaolin). Typical bands of kaolinite in the range of $3697-3621 \mathrm{~cm}^{-1}$ related to $\mathrm{OH}$ stretching disappear after calcination and bands for wavenumbers smaller than $1500 \mathrm{~cm}^{-1}$ become indefinite, indicating amorphous material. The loss of crystallinity after calcination could also be observed by X-ray diffraction, except for the presence of quartz that was already present as a minor phase in kaolinite.

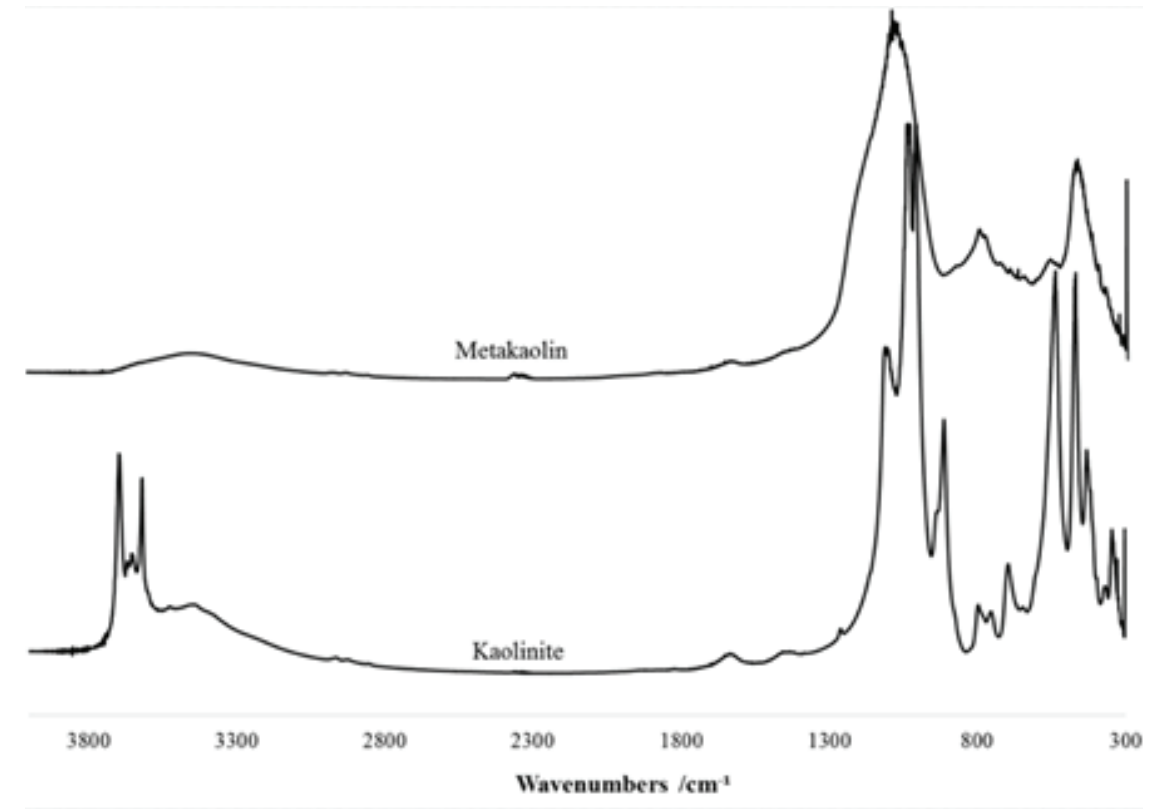

Figure 3: Infrared spectra of the kaolinite and the metakaolin. 
Table 3 shows the decrease of the specific surface area of a kaolinite sample after calcination at $800{ }^{\circ} \mathrm{C}$ with varying heating rate $\left(1\right.$ and $\left.10{ }^{\circ} \mathrm{C} / \mathrm{min}\right)$ and calcination time $\left(4 \mathrm{~h}\right.$ and $8 \mathrm{~h}$ ), treated as a $2^{2}$ factorial design. Figure 4 shows the main effects and interaction plots. The influence of heating rate is greater than the one of calcination time. Concerning the interaction between heating rate and time, the influence of the heating rate is greater at the shorter calcination time.

TABLE 3: Effect of heating rate and calcination time on the decrease of the specific surface for design 1 (see Table 1)
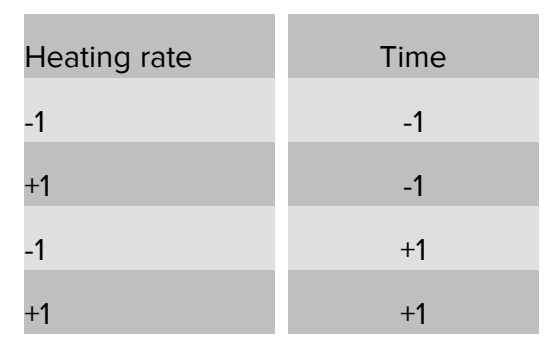

$\mathrm{S}_{g}$ : specific surface

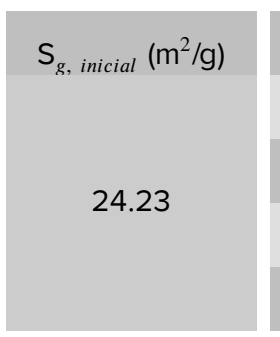

$\mathrm{S}_{g, \text { calcined }}\left(\mathrm{m}^{2} / \mathrm{g}\right)$
19.75
16.35
18.57
16.51

$\Delta \mathrm{S}_{g}\left(\mathrm{~m}^{2} / \mathrm{g}\right)$

$-4.48$

$-7.88$

$-5.66$

$-7.72$

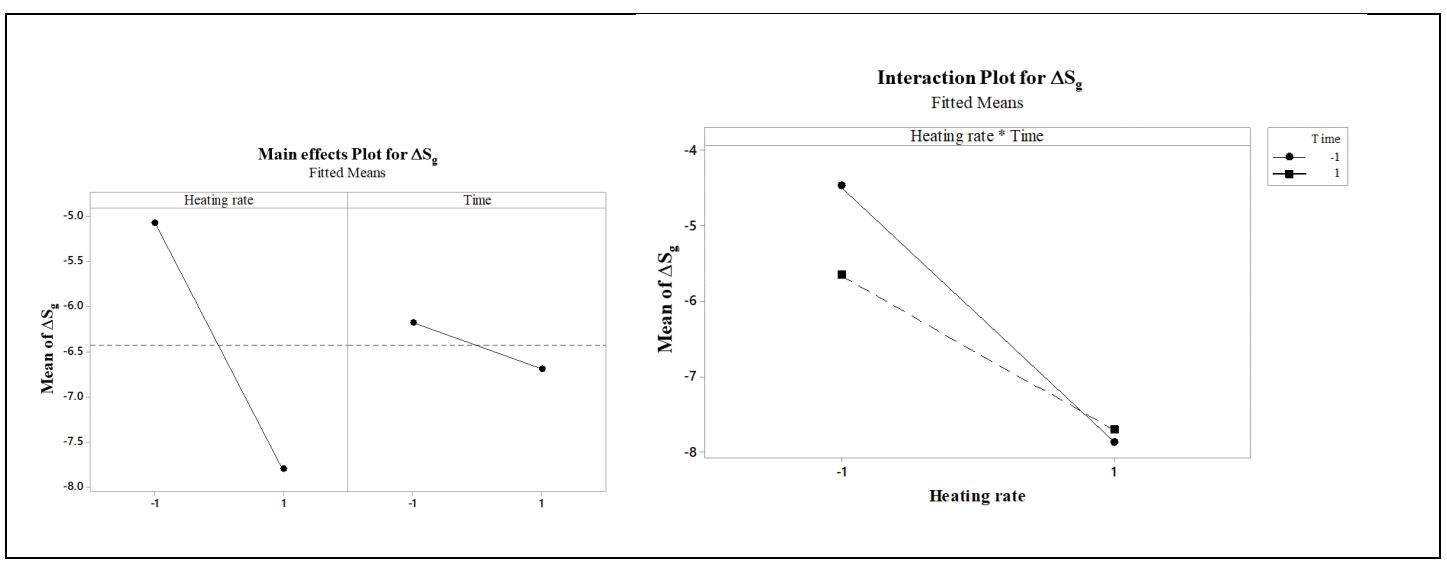

Figure 4: Main effects and interaction plots for the specific surface of the metakaolin, calculated with Minitab

Table 4 shows the results of the compressive strength tests performed on the geopolymer samples after 28 days of curing for the first design including the sample composition. Figure 5 shows a comparison based on the Tukey test assuming equal variances, calculated with Minitab. By comparing Figures $4 a$ and $4 c$ and $4 b$ and $4 d$, one observes that composition A produced higher strength compressions for the heating rate of $10{ }^{\circ} \mathrm{C} / \mathrm{min}$. By comparing Figures $4 \mathrm{a}$ and $4 \mathrm{~b}$ and $4 \mathrm{c}$ and $4 \mathrm{~d}$, one observes that the heating rate of $10{ }^{\circ} \mathrm{C} / \mathrm{min}$ produces higher compressive strengths. Figures $4 \mathrm{a}$ to $4 \mathrm{~d}$ shows that higher calcination times tends to produce higher compressive strengths.

Based on these results the second design of Table 1 was performed in order to study also the influence of the calcining temperature. Table 5 shows the results obtained for the compressive strength. This Table is a replicate of the experiments of the data of 
TABLE 4: Results of compressive strength for the first design of Table 1

\begin{tabular}{|c|c|c|c|c|c|c|c|}
\hline $\mathrm{CT}$ & $\mathrm{HR}$ & C & & & $\mathrm{CS}(\mathrm{MPa}$ & & \\
\hline 1.0 & 1 & A & 31.21 & 43.98 & 43.52 & 22.02 & 13.24 \\
\hline 1.0 & 10 & $A$ & 22.83 & 13.87 & 20.85 & 27.83 & 39.68 \\
\hline 1.0 & 1 & B & 14.00 & 10.32 & 20.34 & 23.90 & 12.32 \\
\hline 1.0 & 10 & B & 15.00 & 15.13 & 17.71 & 13.36 & 16.77 \\
\hline 2.8 & 1 & A & 22.86 & 30.85 & 18.04 & 21.54 & 20.13 \\
\hline 2.8 & 10 & A & 24.64 & 27.97 & 15.53 & $*$ & 17.27 \\
\hline 2.8 & 1 & B & 21.26 & 21.46 & 22.22 & 18.45 & 22.47 \\
\hline 2.8 & 10 & B & 21.50 & 31.42 & 16.75 & 16.22 & 33.46 \\
\hline 4.0 & 1 & A & 30.87 & 37.27 & 34.12 & 24.67 & * \\
\hline 4.0 & 10 & $A$ & 47.65 & 49.34 & 43.33 & 40.72 & 43.81 \\
\hline 4.0 & 1 & B & 36.52 & 31.99 & 33.51 & 45.15 & 33.56 \\
\hline 4.0 & 10 & B & 26.82 & 27.95 & 25.94 & 26.60 & 29.46 \\
\hline 8.0 & 1 & A & 38.09 & 44.09 & 26.92 & 43.29 & 31.81 \\
\hline 8.0 & 10 & A & 50.60 & 51.00 & 67.08 & 46.94 & 50.32 \\
\hline 8.0 & 1 & B & 29.65 & 31.11 & 29.90 & 24.19 & 30.95 \\
\hline 8.0 & 10 & B & 39.92 & 41.46 & 43.25 & 43.86 & 48.81 \\
\hline
\end{tabular}

$\mathrm{CT}$ : calcination time (hours), HR: heating rate $\left({ }^{\circ} \mathrm{C} / \mathrm{min}\right), \mathrm{C}$ : composition, $\mathrm{CS}$ : compression strength

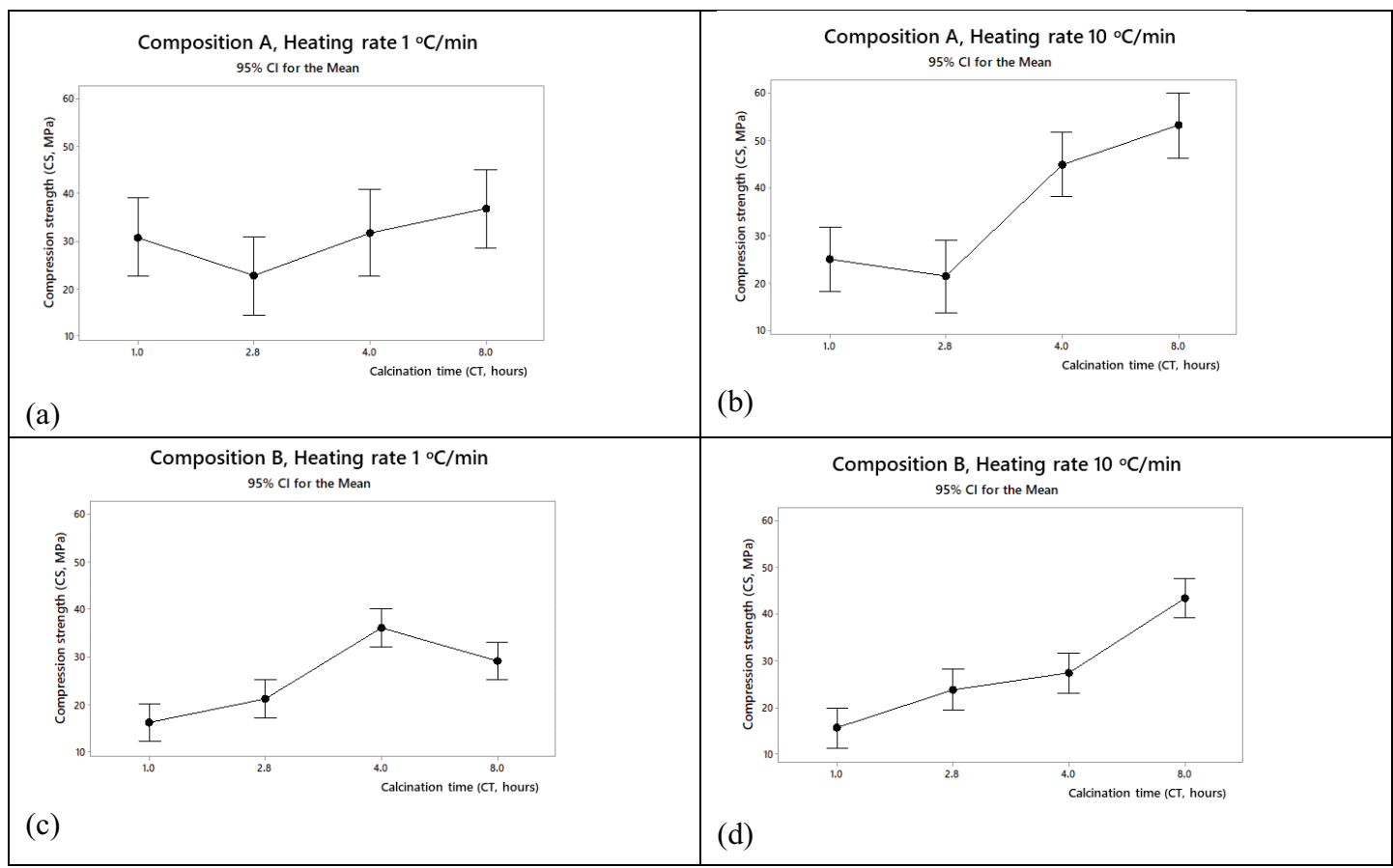

Figure 5: Comparisons of the results of compressive strength (Table 4) based on the Tukey test using pooled standard deviation to calculate the intervals 
Table 4 related to the calcination times of 4 and 8 hours for calcination at $800{ }^{\circ} \mathrm{C}$. A two-sample $t$ test for means comparison with a confidence level of $95 \%$ indicated there is no difference between these replicates.

TABLE 5: Design matrix and responses (compression strength) for the $2^{4}$ factorial design

\begin{tabular}{|c|c|c|c|c|c|c|c|}
\hline \multirow{2}{*}{$\begin{array}{l}\text { C } \\
-1\end{array}$} & \multirow{2}{*}{$\begin{array}{c}\text { CT } \\
-1\end{array}$} & \multirow{2}{*}{$\begin{array}{c}\text { HR } \\
-1\end{array}$} & \multirow{2}{*}{$\begin{array}{l}\mathbf{T} \\
-1\end{array}$} & \multicolumn{4}{|c|}{ CS (MPa) } \\
\hline & & & & 34.23 & 42.14 & 38.14 & 39.18 \\
\hline+1 & -1 & -1 & -1 & 26.97 & 25.65 & 23.01 & 23.23 \\
\hline-1 & + & -1 & -1 & 12.96 & 11.65 & 19.91 & 18.33 \\
\hline+1 & +1 & -1 & -1 & 28.24 & 14.63 & 17.76 & 15.75 \\
\hline-1 & -1 & +1 & -1 & 32.46 & 35.89 & 28.24 & 32.26 \\
\hline+1 & -1 & +1 & -1 & 28.30 & 29.20 & 26.70 & 28.32 \\
\hline-1 & +1 & +1 & -1 & 23.07 & 19.76 & 23.64 & 21.41 \\
\hline+1 & +1 & +1 & -1 & 12.60 & 13.16 & 13.05 & 13.31 \\
\hline-1 & -1 & -1 & +1 & 29.39 & 34.74 & 31.49 & 23.26 \\
\hline+1 & -1 & -1 & +1 & 35.48 & 30.84 & 32.80 & 32.83 \\
\hline-1 & +1 & -1 & +1 & 36.26 & 41.50 & 40.81 & 29.83 \\
\hline+1 & +1 & -1 & +1 & 28.25 & 30.38 & 28.24 & 29.68 \\
\hline-1 & -1 & +1 & +1 & 44.77 & 42.01 & 38.84 & 41.17 \\
\hline+1 & -1 & +1 & +1 & 25.71 & 27.05 & 24.92 & 25.79 \\
\hline-1 & +1 & +1 & +1 & 48.26 & 48.81 & 44.77 & 47.99 \\
\hline+1 & +1 & +1 & +1 & 38.70 & 39.97 & 41.39 & 41.82 \\
\hline
\end{tabular}

C: composition, $\mathrm{CT}$ : calcination temperature, HR: heating rate, $\mathrm{T}$ : calcination time

The data of Table 5 were analyzed with Minitab. A non-hierarchical empirical model including only the significant interactions is

$$
\begin{aligned}
C S(M P a)= & 29.87-3.17 C+1.50 H R+5.69 T-1.87 C T-1.29 C * H R+1.81 H R * T \\
& +1.23 H R * C T+4.86 T * C T-0.97 C * H R * T-0.91 C * T * C T \\
& +0.87 H R * T * C T+2.63 C * H R * T * C T
\end{aligned}
$$

$\mathrm{SE}_{\text {coef }}=0.39, \mathrm{~S}=3.09, \mathrm{R}^{2}=92.01 \%, \mathrm{R}_{\text {adj }}^{2}=90.13 \%, \mathrm{R}_{\text {pred }}^{2}=87,42 \% . \mathrm{C}, \mathrm{HR}, \mathrm{CT}$ and $\mathrm{T}$ are coded factors.

This model has many significant interactions between the main factors, which indicates the complexity of the geopolymeric reactions and how they are influenced by the conditions of the metakaolin production. According to this model, the maximum compression strength, obtained for $\mathrm{C}=-1$ (composition A), $\mathrm{HR}=+1\left(10^{\circ} \mathrm{C} / \mathrm{min}\right), \mathrm{T}=+1$ 
$\left(800{ }^{\circ} \mathrm{C}\right)$, and $\mathrm{CT}=+1$ (8 hours), is between $40.9 \mathrm{MPa}$ and $54.5 \mathrm{MPa}$ for a confidence of $95 \%$, calculated with the response optimizer of Minitab.

The most important term in the model of equation (1) is the interaction between the calcination temperature and the calcination time $\left(T^{*} \mathrm{CT}\right)$. This interaction is synergic, that means, for $700{ }^{\circ} \mathrm{C}(-1)$ the calcination time should be 4 hours $(-1)$ and for $800{ }^{\circ} \mathrm{C}(+1)$ the calcination time should be 8 hours $(+1)$ to produce higher compressive strengths. The combination of $700{ }^{\circ} \mathrm{C}$ for 8 hours or $800{ }^{\circ} \mathrm{C}$ for 4 hours is deleterious for the compressive strength. In overall, the compressive strength is lower at $700{ }^{\circ} \mathrm{C}$ when compared with $800^{\circ} \mathrm{C}$, as shown in the cube plot of Figure 6. It can also be observed that with the combination of composition, calcination temperature, calcination time and heating rate samples of geopolymer with very different compressive strengths can be obtained.

\section{Cube Plot (fitted means) for CS}

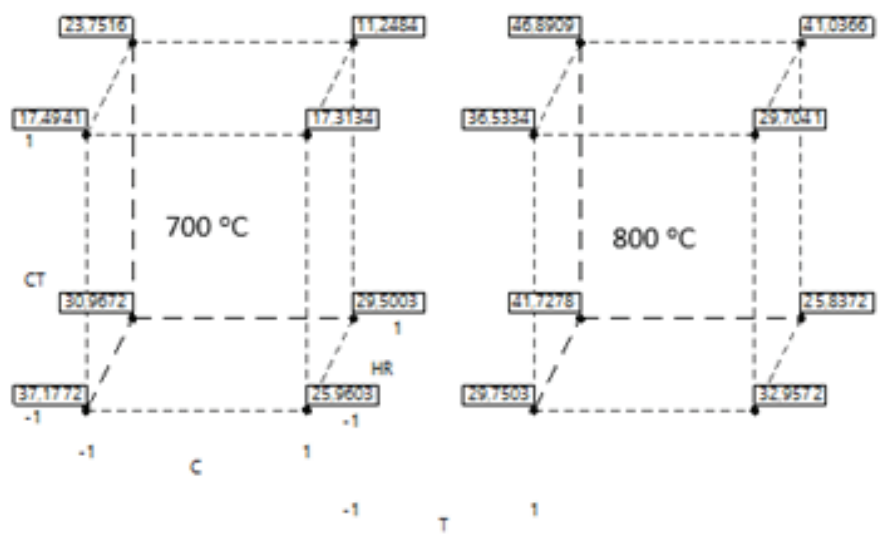

Figure 6: Cube plot for the compressive strength (CS) based on the empirical model of equation (1). T: calcining temperature, $\mathrm{C}$ : composition, HR: heating rate

Figure 7 shows the compressive strength (CS) as a function of the decrease of the specific surface $\left(\Delta \mathrm{S}_{g}\right)$ in the calcination. A correlation exists for composition $A$, but it is not clear for composition B. For composition A, the compressive strength increases with the decrease of the specific surface.

\section{Conclusion}

Samples of geopolymer were obtained with the use of kaolinite generated as a byproduct from sand extraction in the municipality of Inhaúma (Minas Gerais, Brazil). The samples of kaolinite were calcined at different temperatures, times and heating rates 


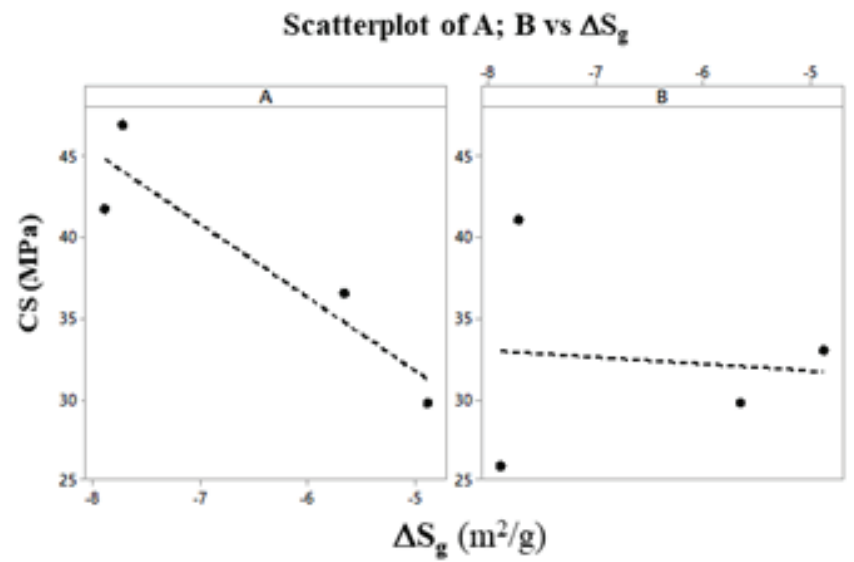

Figure 7: Compressive strength of geopolymer samples (CS) as a function of the decrease of the specific surface $\left(\Delta \mathrm{S}_{g}\right)$ in the calcination of kaolinite.

of the kiln. The geopolymer samples were synthesized with different proportions of metakaolin, alkaline sodium silicate and sodium hydroxide solution. A strong influence of the composition of the geopolymer samples, calcination temperature, kiln heating rate, and calcination time on the compressive strength was observed, as well as synergistic and antagonistic interactions between two, three, and four factors indicating the complexity of the geopolymeric reactions. According to the empirical model calculated from a $2^{4}$ factorial design, the compressive strengths observed may range from $10 \mathrm{MPa}$ to $55 \mathrm{MPa}$, revealing the need for a rigid control over these factors to obtain geopolymer samples with the desired compressive strength.

\section{Acknowledgments}

To Midas Institute of Science and Technology, CNPq, CAPES and Fapemig.

\section{References}

[1] Boca Santa, R. A. A., Soares, C., and Riella, H. G. (2017). Geopolymer obtained from bottom ash as source of aluminosilicate cured at room temperature. Construction and Building Materials, vol. 157, pp. 459-466; Mikilčić, H., et al (2013). $\mathrm{CO}_{2}$ emission reduction in the cement industry. CEt - Chemical Engineering Transactions, vol. 35, pp. 703-708.

[2] Sharma, R. (2017). Cement Industry Trends Report. (India: TERI), p.17.

[3] Davidovits, J. (2002). 30 years of successes and failures in geopolymer applications. Market trends and potential breakthroughs. Geopolymer 2002 Conference, October 
28-29, Melbourne, Australia; Davidovits, J. (2005) Geopolymer chemistry and applications. $4^{\text {th }}$ Edition. (Saint Quentin: Insitut Géopolumère), p. 644.

[4] Boca Santa, R. A. A., Soares, C., and Riella, H. G. (2017). Geopolymer obtained from bottom ash as source of aluminosilicate cured at room temperature. Construction and Building Materials, vol. 157, pp. 459-466; Turner, L. K. and Collins, F. G. (2013) Carbon dioxide equivalent $\left(\mathrm{CO}_{2}\right.$-e) emissions: A comparison between geopolymer and OPC cement concrete. Construction and Building Materials, vol. 43, pp. 125-130.

[5] Ye, N. et al. (2014). Synthesis and characterization of geopolymer from Bayer red mud with thermal pretreatment. Journal of the American Ceramic Society, pp. 1652-1660.

[6] ABNT, 2007. NBR 5739 Concreto - Ensaio de compressão de corpos-de-prova cilindricos, Associação Brasileira de Normas Técnicas. 